\title{
KETERAMPILAN CALON GURU SD DALAM MENERAPKAN MEDIA PEMBELAJARAN IPA BERBASIS IT TERHADAP HASIL BELAJAR SISWA SDN-5 PANARUNG PALANGKA RAYA
}

\author{
RITA RAHMANIATI \\ Dosen Program Studi Pendidikan Guru Sekolah Dasar Fakultas Keguruan dan IImu Pendidikan \\ Universitas Muhammadiyah Palangkaraya \\ Email : rahmaniatirita@yahoo.co.id
}

\begin{abstract}
Problems in learning science (IPA) that occurs to the students of SDN 5 Panarung Palangka Raya is the use of learning media that often done by teacher but it has not been able to give the optimum results. It was signed by the students who can not follow the lesson well because they were tired, and do not have the braveness to argue or give a different idea according to the views and understanding that is in students themselves. This study is aimed to describe the skills of student teachers in implementing learning media based IT. The indicators to measure the achievement of the study conducted by using the principles of qualitative research.

The results showed that the implementation of learning by students teacher in SD by using media based IT with good category with an average score of 3.05. Students' activity during the learning with media based IT is categorized good on the activity of carrying out the assignment that given by teacher (29.5\%). Learning by using learning media based IT can improve students' learning outcomes. It showed that the learning had been centered to the students.
\end{abstract}

Keywords: elementary student teacher' skill, students' learning outcomes

\section{ABSTRAK}

Permasalahan pembelajaran IPA yang terjadi pada siswa SDN 5 Panarung Palangka Raya adalah penggunaan media pembelajaran yang sering dilakukan guru tetapi belum dapat memberikan hasil optimal yang ditandai dengan siswa belum dapat menyimak pembelajaran dengan baik karena merasa jenuh, dan belum memiliki keberanian dalam berpendapat atau menyumbangkan ide yang berbeda menurut pandangan dan pemahaman yang ada pada diri siswa yang sebenarnya. Penelitian ini bertujuan mendeskripsikan keterampilan mahasiswa calon guru dalam menerapkan media pembelajaran berbasis IT. Untuk mengukur ketercapaian indikator penelitian tersebut dilakukan penelitian menggunakan prinsip prinsip penelitian kualitatif.

Hasil penelitian menunjukkan bahwa pelaksanaan pembelajaran oleh mahasiswa calon guru SD dengan media berbasisi IT pada kategori baik dengan rata rata skor 3.05. Aktivitas siswa selama pembelajaran dengan media pembelajaran berbasis IT berkategori baik pada aktivitas melaksanakan tugas yang diberikan guru (29.5\%). Pembelajaran dengan menggunakan media pembelajaran berbasis IT mampu meningkatkan hasil belajar siswa. Hal ini menunjukkan bahwa pembelajaran sudah berpusat pada siswa.

Kata kunci : keterampilan calon guru SD, hasil belajar siswa

\section{PENDAHULUAN}

Berdasarkan pengalaman dalam membimbing PPL 2 selama 3 bulan di SDN-5 Panarung Palangka Raya, ditemukan masih banyak calon guru yang belum terampil mengajar dengan menggunakan media, terutama media yang berbasis IT. Dari mahasiswa PPL tersebut hanya $25 \%$ yang telah terampil mengajar dengan menggunakan media, sementara itu sekitar $75 \%$ masih belum terampil mengajar dengan menggunakan media. Kondisi ini perlu segera di 
benahi, untuk meningkatkan aktivitas selama proses pembelajaran dan memperoleh hasil belajar siswa yang optimal.

Aktivitas belajar siswa pada umumnya masih rendah. Rendahnya aktivitas ini ditandai dengan masih banyak siswa yang belum memberikan respon ketika guru mengajukan pertanyaan atau saat diberikan kesempatan bertanya, belum dapat menyimak pembelajaran dengan baik karena merasa jenuh, dan belum memiliki keberanian dalam berpendapat atau menyumbangkan ide yang berbedaan menurut pandangan dan pemahaman yang ada pada diri siswa yang sebenarnya. Kondisi ini jika dibiarkan akan berdampak pada hasil belajar siswa.

Hasil belajar siswa dapat optimal jika pembelajaran di desain dan dilaksanakan dengan benar. Sebaliknyasebuah pembelajaran tidak dirancang dan dilaksanakan dengan benar maka akan dapat menurunkan hasil belajar siswa. Pembelajaran dirancang dengan benar di antaranya, memperhatikan tujuan, bahan ajar, metode dan evaluasi. Selain itu, hasil belajay yang optimal ditentukan oleh pemilihan media yang tepat serta keterampilan guru dalam mempraktekannya.

Keterampilan mengajar guru adalah seperangkat kemampuan/kecakapan guru dalam melatih/membimbing aktivitas dan pengalaman seseorang serta membantunya berkembang dan menyesuaikan diri kepada lingkungan. Jadi, persepsi siswa tentang keterampilan mengajar guru adalah penilaian berupa tanggapan/pendapat siswa terhadap kemampuan/kecakapan guru dalam proses kegiatan belajar mengajar.
Turney (Uzer Usman, 2010) mengemukakan ada 8 (delapan) keterampilan mengajar/membelajarkan yang sangat berperan dan menentukan kualitas pembelajaran, diantaranya 1) keterampilan bertanya 2) keterampilan mempeberikan penguatan 3) keterampilan mengadakan variasi 4) keterampilan menjelaskan 5) keterampilan membuka dan menutup pelajaran 6) keterampilam membimbing diskusi kelompok kecil 7) keterampilan mengelola kelas 8) keterampilan mengajar kelompok kecil dan perorangan.

Berdasarkan ke delapan keterampilan dasar yang harus dikuasai guru, keterampilan mengadakan variasi pembelajaran dengan menggunakan media merupakan salah satu hal penting yang turut menentukan peningkatan aktivitas dan hasil belajar siswa. Manfaat media dalam pembelajaran sebagai berikut a) Penyampaian pelajaran menjadi lebih baku b) Pembelajaran bisa lebih menarik c) Pembelajaran menjadi lebih interaktif d) Lama waktu pembelajaran yang diperlukan dapat dipersingkat. e) Kualitas hasil belajar dapat ditingkatkan f) Pembelajaran dapat diberikan kapan dan dimana diinginkan atau diperlukan g) Sikap positif peserta didik h) Peran pembelajaran dapat berubah kearah yang lebih positif (Jennah, 2009).

\section{METODOLOGI}

\section{Metode Penelitian}

Penelitian ini dilakukan dengan metode kualitatif melalui keterampilan dalam menerapkan media pembelajaran berbasis IT oleh calon guru di SDN-5 Panarung Palangka Raya sebanyak 2 kali pertemuan di kelas 3,4 dan 5 semester 1 
pada materi Penggolongan Makhluk Hidup, Sistem Indera dan Sistem Pernafasan pada Manusia. Secara ringkas alur rancangan pelaksanaan penelitian ini digambarkan melalui gambar 1.

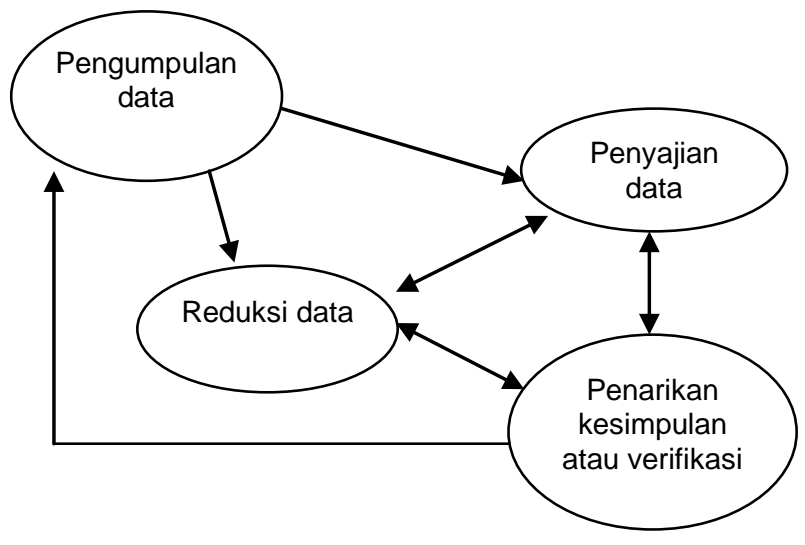

Gambar 1. Komponen Analisis Data Model Interaktif

Penelitian dilaksanakan di kelas 3, 4 dan 5 SDN 5 Panarung semester ganjil tahun pelajaran 2015/2016 menggunakan media pembelajaran IPA berbasis IT oleh calon guru SD. Pemilihan tempat penenlitian ini karena sekolah bersangkutan memiliki masalah terhadap proses pembelajaran khusus nya pada materi Penggolongan Makhluk hidup, sistem indera dan sistem pernafasan pada manusia serta sekolah memberikan izin peneliti untuk mengadakan penelitian mengenai masalah keterampilan karena calon guru yang di teliti adalah mahasiswa UM Palangkaraya yang melaksanakan PPL (Praktek Pengalaman Lapangan).

Jenis data yang dikumpulkan dalam penelitian ini adalah data yang berkaitan dengan data keterlaksanaan pembelajaran, aktivitas siswa dan hasil belajar dan respon siswa kelas 5 SDN-5 Panarung Kota Palangka Raya.
Prosedur pengumpulan data yang di gunakan dalam penelitian ini melalui metode observasi/pengamatan, tes, dan angket.

1. Untuk memperoleh data keterlaksanaan pembelajaran oleh calon guru dengan menggunakan media berbasis IT diperoleh melalui lembar observasi dengan cara observasi.

2. Untuk memperoleh data tentang aktivitas siswa pada pembelajaran dengan menggunakan media berbasis IT diperoleh melalui lembar observasi dengan cara observasi

3. Untuk memperoleh data tentang hasil belajar sebelum dan sesudah pembelajaran dengan menggunakan media berbasis IT diperoleh melalui soal pretest dan posttest.

4. Untuk memperoleh data respon siswa terhadap pembelajaran dengan menggunakan media berbasis IT diperoleh melalui angket siswa.

Berdasarkan instrumen penelitian, maka analisis data yang digunakan adalah :

1. Data tentang keterlaksanaan pembelajaran oleh calon guru dengan menggunakan media berbasis IT dianalisis menggunakan deskriptif kualitatif.

2. Data tentang aktivitas siswa pada pembelajaran dengan menggunakan media berbasis IT dianalisis menggunakan deskriptif kualitatif.

3. Data tentang hasil belajar pretest dan postes pembelajaran dengan menggunakan media berbasis IT dianalisis menggunakan N-Gain.

4. Data Respon Siswa terhadap pembelajaran dengan menggunakan media berbasis IT dianalisis menggunakan deskriptif kualitatif. 


\section{HASIL DAN PEMBAHASAN}

\section{Keterlaksanaan Pembelajaran}

Secara keseluruhan keterampilan calon guru dalam menggunakan media pembelajaran berbasis IT di SDN 5 Panarung dengan kategori baik. Hal ini dapat terlihat dari rata rata pelaksanaan pembelajaran di kelas 3, 4 dan kelas 5. Keterampilan guru dalam melaksanakan pembelajaran dominan pada memotivasi siswa (3,3 kategori baik), keterampilan membuka pelajaran (3,25 kategori baik) keterampilan menjelaskan (3,3 kategori baik) keterampilan menggunakan media berbasis IT (3,3 kategori baik) dan keterampilan mengaitkan media dengan materi (3,3 kategori baik). Skor rata-rata keterlaksanaan pembelajaran calon guru secara keseluruhan yaitu 3.05 pada kategori baik. Berdasarkan penilaian 4 orang pengamat hampir keseluruhan keterampilan calon guru dalam pembelajaran IPA menggunakan media pembelajaran berbasis IT sudah baik.

\section{Aktivitas Siswa}

Presentase aktivitas siswa selama proses pembelajaran berlangsung digambarkan pada gambar 2. Aktivitas siswa yang tampak dominan melaksanakan tugas yang diberikan guru (29.5\%), memperhatikan penjelasan guru sebelum dan sesudah menyampaikan tujuan pembelajaran (22.2\%) dan membuat/menuliskan rangkuman pelajaran (12,2\%). Sedangkan aktivitas guru yang dominan dilakukan selama KBM dengan Model PBI adalah membimbing siswa mengerjakan tugas (24.4\%), menjelaskan materi IPA kepada siswa berdasarkan buku siswa (19.7\%), dan menggunakan media pembelajaran berbasis IT dan meminta siswa menyimak (10.9\%) dari keseluruhan KBM.

Fakta tersebut memberikan gambaran bahwa pembelajaran IPA dengan menggunakan media berbasis IT mampu mengurangi dominasi guru untuk berceramah yang umum dilakukan dalam pembelajaran sehari-hari, berkurangnya dominasi guru dalam kegiatan ceramah membuat siswa memiliki lebih banyak waktu untuk melakukan aktivitas yaitu melaksanakan tugas yang diberikan guru dan diskusi.

\section{Hasil Belajar}

Presentase pencapaian hasil belajar siswa SDN 5 Panarung secara ringkas digambarkan pada gambar 3 . Adanya peningkatan hasil belajar dari pretest dan postes baik di kelas 3 (pretest 28,57 menjadi 72,32), kelas 4 (pretest 41,25 menjadi 75,5) dan kelas 5 (pretest 41,43 menjadi 73,04). Hal ini menunjukkan adanya respon belajar yang baik dari siswa terhadap pembelajaran yang diciptakan oleh calon guru dengan menggunakan media pembelajaran IPA berbasis IT. Pembelajaran IPA dengan menggunakan media berbasis IT mampu memvisualisasikan hal hal yang bersifat abstrak menjadi konkrit sehingga membantu siswa mempermudah pemahaman tentang materi yang diajarkan oleh guru/ calon guru. Pemanfaatan ilmu teknologi dan informasi (IT/ICT) sebagai media yang mendukung proses pembelajaran serta memudahkan calon guru dalam menyampaikan dan memberikan pengertian kepada siswa terhadap materi yang diajarkan, selain itu dapat memberikan pengalaman baru bagi siswa yang terlalu jenuh dengan model pembelajaran konvensional yang dilakukan guru selama ini. Hal ini senada dengan pendapat 


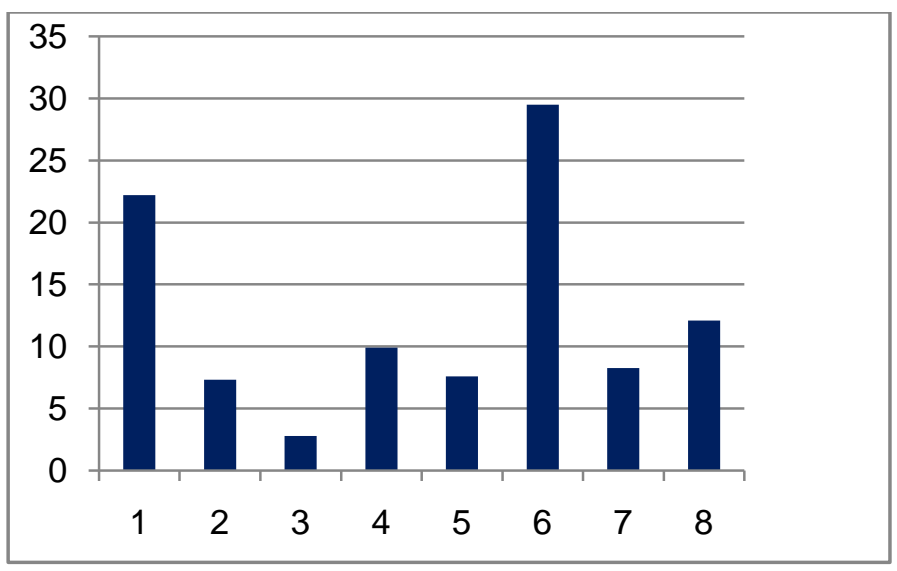

Keterangan :

1. Memperhatikan penjelasan guru sebelum dan sesudah menyampaikan tujuan pembelajaran.

2. Membaca buku siswa tentang materi IPA

3. Menulis yang releven dengan KBM

4. Memperhatikan tayangan video yang disajikan guru.

5. Menunjukkan ketertarikan kepada media berbasis IT yang gunakan guru dikelas

6. Melaksanakan tugas yang diberikan guru

7. Berdiskusi antar siswa/kelompok/guru

8. Membuat/menuliskan rangkuman pelajaran

Gambar 2. Presentase pencapaian hasil belajar siswa SDN 5 Panarung

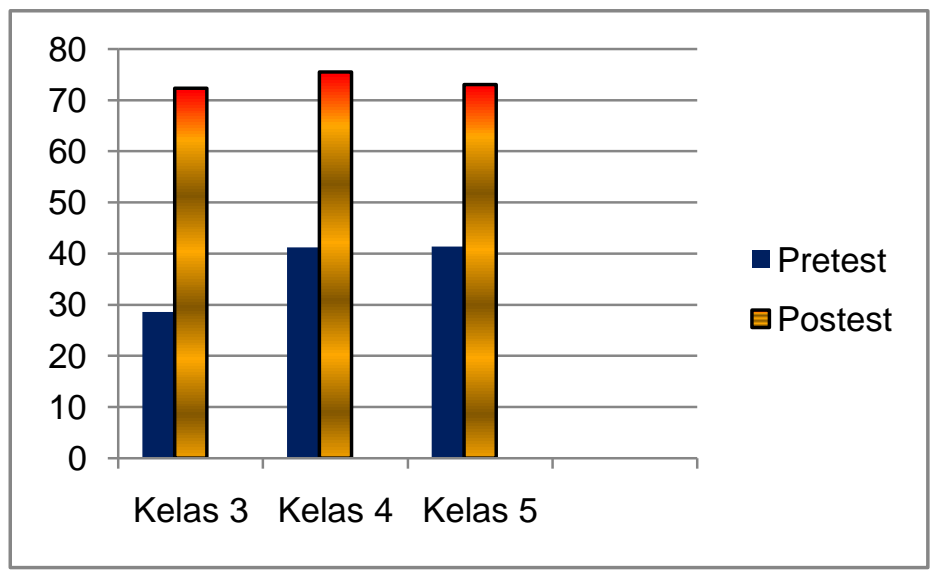

Gambar 3. Presentase pencapaian hasil belajar siswa SDN 5 Panarung

Kemp \& Dayton (Jennah, 2009 : 22-24) manfaat Media pembelajaran yaitu : 1) Penyampaian pelajaran menjadi lebih baku 2) Pembelajaran bisa lebih menarik 3) Pembelajaran menjadi lebih interaktif 4) Lama waktu pengajaran yang diperlukan dapat dipersingkat 5) Kualitas hasil belajar dapat ditingkatkan 6) Pembelajaran dapat diberikan kapan dan dimana diinginkan atau diperlukan 7) Sikap positif pembelajar 8) Peran pembelajar dapat berubah kearah yang lebih positif. Dengan demikian keterampilan guru dalam mengadakan variasi pembelajaran salah satunya dengan menggunakan media pembelajaran merupakan salah satu hal penting yang turut 
menentukan peningkatan aktivitas dan hasil belajar siswa.

\section{Respon Siswa}

Data respons siswa terhadap pembelajaran diperoleh dari angketrespon siswa. Angket diberikan setelah seluruh pembelajaran berakhir, yang dikuti oleh 78 siswa yang terdiri dari kelas 3 , kelas 4 dan kelas 5 . Pertanyaan perteanyaan dalam angket jika dibuat dalam bentuk tabel dan disesuaikan dengan jawaban siswa, yang terbagi kedalam beberapa beberapa kelompok seperti yang tergambar tentang respon siswa terhadap kegiatan pembelajaran.

Persentase respon siswa untuk angket No 1, 2 dan 5 diperlihatkan melalui gambar 4 . Persentase respons siswa untuk angket No. 5 diperlihatkan melalui gambar 5. Persentase respons siswa untuk angket No. 6 diperlihatkan melalui gambar 6 .
Berdasarkan hasil angket respon siswa menyatakan cara mengajar guru dan cara belajar siswa sangat menyenangkan dan menarik serta merupakan hal baru. Hal ini memberikan makna bahwa siswa merasa senang dengan penggunanan media pembelajaran berbasis IT pada proses belajar mengajar. Sebagian besar siswa berpendapat baru mengikuti pembelajaran dengan, penggunanan media pembelajaran berbasis IT pada proses pembelajaran. sedangkan sisanya menganggap tidak baru. Hal ini mungkin disebabkan karena siswa mengannggap tontonan video dan sejenisnya yang dikemas dalam pembelajaran dikelas mirip ketika mereka menonton tv di rumah. Meskipun begitu secara keseluruhan siswa merasa bahwa model pembelajaran ini bermanfaat bagi mereka, dan berharap untuk materi lainnya dapat menggunakan media pembelajaran berbasis IT.



Gambar 4. Respon siswa untuk angket no 1, 2 dan 5 


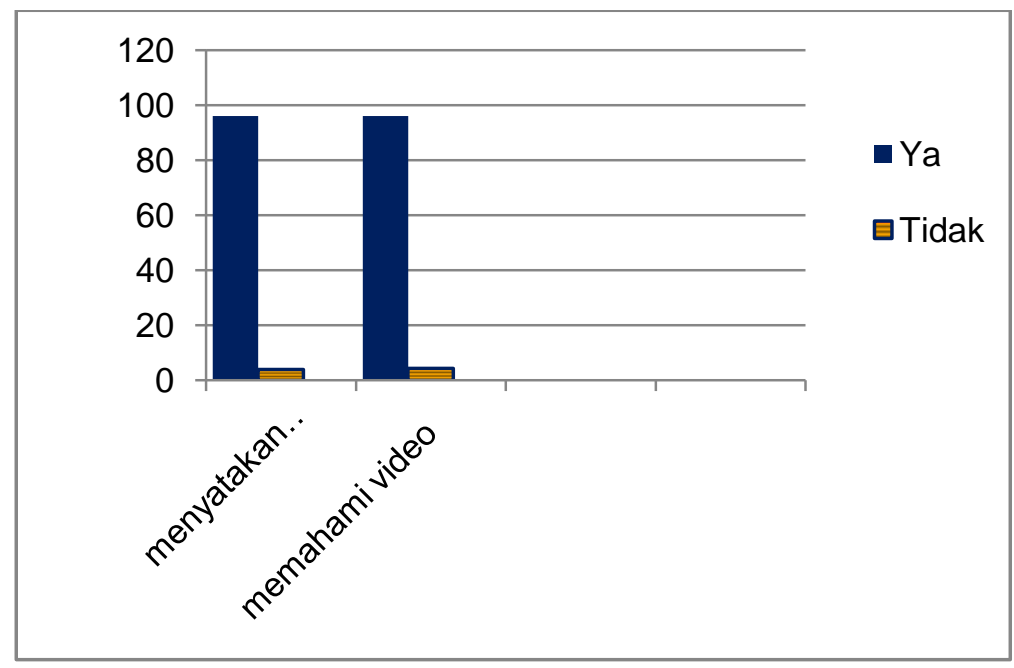

Gambar 5. Presentase respons siswa untuk angket no.5

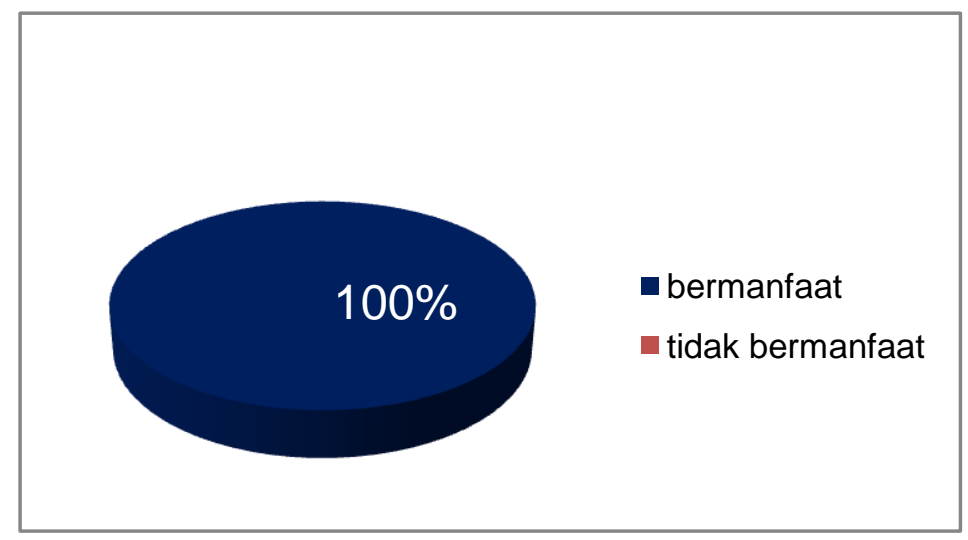

Gambar 6. Presentase respons siswa untuk angket no.6

\section{KESIMPULAN}

Berdasarkan hasil penelitian dan pembahasan dapat disimpulkan bahwa:

1. Pelaksanaan pembelajaran oleh mahasiswa calon guru SD dengan media berbasisi IT pada kategori baik dengan rata rata skor 3.05.

2. Aktivitas siswa selama pembelajaran dengan media pembelajaran berbasis IT berkategori baik pada aktivitas melaksanakan tugas yang diberikan guru (29.5\%). Hal ini menunjukkan bahwa pembelajaran sudahberpusat pada siswa.
3. Keterampilan guru SD dalam menerapkan Media pembelajaran IPA berbasis IT terhadap hasil belajar Siswa SDN-5 Panarung Palangka Raya pada kategori baik karena mampu meningkatkan hasil belajar siswa.

\section{DAFTAR PUSTAKA}

Arsyad, Azhar. 2011. Media Pembelajaran. Jakarta: Rajawali

Departemen Pendidikan Nasional. 2006. Peraturan Lampiran Menteri Pendidikan Nasional No. 22 tahun 2006 Tentang Standar Isi. Jakarta: Depdiknas. 
Departemen Pendidikan Nasional. 2006. Pembelajaran Sains Menurut Kurikulum 2006. Jakarta: Depdiknas.

Departemen Pendidikan Nasional. 2007. Peraturan Menteri Pendidikan Nasional No 41 Tahun 2007 Tentang Standar Proses. Jakarta: Depdiknas.

Dimyati, Mudjiono. 2006. Belajar dan Pembelajaran. Jakarta: Rhineka Cipta.

Hamalik, O. 2006. Proses Belajar Mengajar. Jakarta: PT. Bumi Aksara

Ikhsanudin dkk. 2007. Pembelajaran Berbasis Teknologi Informasi Untuk Meningkatkan Pemahaman Konsep, Keterampilan Generik Sains dan Berpikir Kritis Siswa pada Topik Hidrolisis Garam dan Sifat Koligatif Larutan. Tesis. Bandung : Universitas Pendidikan Indonesia.

Jennah. 2009. Media Pembelajaran. Banjarmasin: Antasari Press.

Natawijaya, Rochman. 2005. Aktivitas Belajar. Jakarta: Depdiknas

Republik Indonesia. 2007. Peraturan Menteri Pendidikan Nasional No 16 Tahun 2007 tanggal 4 Mei 2007 tentang Standar Kualifikasi Akademik dan Kompetensi Guru. Jakarta

Republik Indonesia. 2008. Peraturan Pemerintah Republik Indonesia No 74 Tahun 2008 tentang Guru. Jakarta.

Rochimah. 2011. Penerapan FIELD Study untuk Peningkatan Aktivitas dan Prestasi Belajar Fisika pada Siswa Kelas XI IPA Madrasah Aliyah An Nabawi Berjan Purwokerto. Skripsi. Universitas Muhammadiyah Perwokerto.

Sanjaya, Wina, 2006. Strategi Pembelajaran Berorientasi Standar Proses Pendidikan. Jakarta: Kencana.

Siregar, Eveline dan Nara, Hartini. 2010. Teori Belajar dan Pembelajaran. Bogor: Gahlia Indonesia.
Slameto. 2010. Belajar dan Faktor-faktor Yang Mempengaruhinya. Jakarta: Rineka Cipta.

Tu'u, Tulus. 2004. Peran Disiplin pada Perilaku dan Prestasi Siswa. Jakarta: Grasindo.

Uno, Hamzah. 2009. Perencanaan Pembelajaran. Jakarta: Bumi Aksara.

Usman, M. Uzer. 2010. Menjadi Guru Profesional. Bandung: PT. Remaja. 